REVIEW

\title{
Genetics of dyslexia: the evolving landscape
}

\author{
Johannes Schumacher, Per Hoffmann, Christine Schmäl, Gerd Schulte-Körne, Markus M Nöthen
}

J Med Genet 2007;44:289-297. doi: 10.1136/jmg.2006.046516

Dyslexia is among the most common neurodevelopmental disorders, with a prevalence of 5-12\%. At the phenotypic level, various cognitive components that enable reading and spelling and that are disturbed in affected individuals can be distinguished. Depending on the phenotype dimension investigated, inherited factors are estimated to account for up to $80 \%$. Linkage findings in dyslexia are relatively consistent across studies in comparison to findings for other neuropsychiatric disorders. This is particularly true for chromosome regions 1p34-p36, 6p21-p22, 15q21 and $18 q 11$. Four candidate genes have recently been identified through systematic linkage disequilibrium studies in linkage region $6 \mathrm{p} 21-\mathrm{p} 22$, and through cloning approaches at chromosomal breakpoints. Results indicate that a disturbance in neuronal migration is a pathological correlate of dyslexia at the functional level. This review presents a summary of the latest insights into the genetics of dyslexia and an overview of anticipated future developments.

See end of article for authors' affiliations

Correspondence to: Professor M M Nöthen, Department of Genomics, Life \& Brain Centre, University of Bonn, Sigmund-Freud-Strasse 25, D-53105 Bonn, Germany; markus.noethen@ uni-bonn.de

Received

20 September 2006

Revised 13 January 2007

Accepted 22 January 2007

Published Online First

16 February 2007
$\mathrm{D}$ yslexia is among the most common neurodevelopmental disorders, with a prevalence of $5-12 \% .^{12}$ The prevalence varies with the use of different diagnostic criteria and, since reading and spelling are normally distributed in the population, is influenced by the cut-off point applied to the psychometric tests. According to the International Classification of Diseases-10, dyslexia is "a disorder manifested by difficulty learning to read despite conventional instruction, adequate intelligence and sociocultural opportunity". ${ }^{3}$ Longitudinal studies have shown that the disorder involves an extremely stable developmental disturbance that does not, in contrast to popular opinion, disappear with adolescence. ${ }^{4}$ The psychosocial consequences are correspondingly grave. Affected individuals attain a much lower educational level and have substantially higher rates of unemployment and psychosocial stress than would be expected for their level of intelligence. $^{5-7}$ In childhood, approximately $20 \%$ of those with dyslexia also present with attention-deficit hyperactivity disorder (ADHD), ${ }^{8-12}$ whereas in adolescence depressive disorders and disorders of social behaviour are often associated with dyslexia. ${ }^{13-15}$ Whether dyslexia is more common among boys than girls has been part of a controversial discussion in the past, although recent epidemiological studies indicate a twofold increase in the risk for boys compared with that in girls. $^{216}$ The sex ratio may be influenced by severity, IQ and assessed cognitive profiles. ${ }^{17}$
Familial clustering in dyslexia was recognised a few years after the first description of the disorder by Hinshelwood in $1895 .^{18-20}$ A child with an affected parent has a risk of $40-60 \%$ of developing dyslexia. This risk is increased when other family members are also affected. ${ }^{19}{ }^{21-25}$ There is an estimated 3-10-fold increase in the relative risk for a sibling $\left(\lambda_{s}\right)$, with an increase in $\lambda_{\mathrm{s}}$ observed when strict criteria are applied. ${ }^{25}$ Twin studies have confirmed that genetic factors are substantially responsible for the familial clustering of dyslexia. ${ }^{17} 26$ The proportion of inherited factors involved in the development of dyslexia is between $40 \%$ and $80 \%$, the highest estimates being reported for the phenotype dimensions word reading (up to $58 \%$ ) and spelling (70\%). ${ }^{17} 26$ Twin studies have allowed for the estimation of heritabilities and also the impact of shared and non-shared environmental factors. Although shared environmental effects are low for word reading, they are substantially higher (at about 14\%) for reading and spelling correlated traits-for example, phonological awareness. ${ }^{27}$

Whether or not sex has an influence on heritability is controversial. Although the results of a US American twin study (Colorado Twin Study) showed similar heritability between the sexes, ${ }^{28}{ }^{29}$ Harlaar et $a l^{30}$ found a higher heritability for boys in a UK sample (London Twins Early Development Study).

Through molecular genetic linkage studies in families with dyslexia, chromosome regions have been identified in which the presence of dyslexia susceptibility genes is suspected. As with all complex disorders, linkage findings are not completely overlapping between independent studies. However, greater consistency is reported for dyslexia than for most other neuropsychiatric disorders, and the identification of the first candidate genes therefore came as no surprise.

This review presents the current state of molecular genetic research on dyslexia, including discussion of the phenotypic aspects and neuropsychological concepts of dyslexia that have received increasing consideration in genetic research over recent years. Finally, the extent to which our understanding of dyslexia is likely to be increased through the results of current and future molecular genetic research is discussed.

Abbreviations: $A D H D$, attention-deficit hyperactivity disorder; CNS, central nervous system; DCDC2, doublecortin domain containing protein 2; DYX1, dyslexia susceptibility 1; DYX9, dyslexia susceptibility 9; DYX1C1, dyslexia susceptibility 1 candidate 1 ; LD, linkage disequilibrium; QTL, quantitative trait loci; $\mathrm{ROBO}$, roundabout Drosophila homolog of 1; SSD, speech-sound disorder 
Table 1 Cognitive components involved in reading and writing

\begin{tabular}{|c|c|}
\hline ent & mark \\
\hline Visual pr & $\begin{array}{l}\text { The magnocellular system responds to moving stimuli } \\
\text { and stimuli of low spatial frequency and low contrast. } \\
\text { Impaired perception of moving stimuli and the } \\
\text { neurophysiological correlates of this have been found } \\
\text { repeatedly in individuals with dyslexia. The exact nature } \\
\text { of this deficiency and its potential relationship to } \\
\text { dyslexia is not yet clear }\end{array}$ \\
\hline $\begin{array}{l}\text { Phonol } \\
\text { awarer }\end{array}$ & $\begin{array}{l}\text { The ability to perceive, segment and manipulate the } \\
\text { sounds of spoken words. }{ }^{31} \text { Phonemes are the smallest } \\
\text { meaningfully distinct sounds from which an acoustic } \\
\text { speech flow can be constructed. The word dog, for } \\
\text { example, consists of three phonemes } / \mathrm{d} /, / \mathrm{l} / \mathrm{g} / \mathrm{g} / \\
\text { The capacity for phonological awareness is often tested } \\
\text { through a phoneme deletion task }\end{array}$ \\
\hline $\begin{array}{l}\text { Verbal s } \\
\text { memory }\end{array}$ & $\begin{array}{l}\text { Various aspects of memory are required for reading. } \\
\text { Many known words are no longer dissected into their } \\
\text { phonemes, but are recalled directly from memory. } \\
\text { Processing of unknown words into their phonemes } \\
\text { occurs in short-term memory. Short-term memory is } \\
\text { offen examined by a digit span task }\end{array}$ \\
\hline $\begin{array}{l}\text { Phon } \\
\text { codin }\end{array}$ & $\begin{array}{l}\text { The ability to put together the phonemes and then } \\
\text { verbally express words which have never been } \\
\text { previously read or heard. This ability is tested through } \\
\text { reading of pseudowords }\end{array}$ \\
\hline $\begin{array}{l}\text { Orth } \\
\text { codi }\end{array}$ & $\begin{array}{l}\text { Orthographic coding refers to the assumed process of } \\
\text { recognising a word by its holistic form. Orthographic } \\
\text { coding is measured by a pseudohomophone task where } \\
\text { an orally presented word has to be compared with a } \\
\text { visual presentation of two phonologically } \\
\text { indistinguishable words, of which one may be } \\
\text { orthographically correct }\end{array}$ \\
\hline Rap & $\begin{array}{l}\text { Rapid naming is a measure of the speed of processing. } \\
\text { The naming of objects, numbers, letters and colours is } \\
\text { typically measured }\end{array}$ \\
\hline
\end{tabular}

\section{PHENOTYPIC ASPECTS AND NEUROPHYSIOLOGICAL} THEORIES

In general, the cognitive processes on which reading and spelling are based are complex, and differing cognitive dimensions ease the separate skills of reading and spelling. Such processes include those of short-term memory, phonological awareness, rapid naming, and phonological and orthographic coding (table 1). In recent years, several theories have been developed with the aim of characterising the basic processes underlying dyslexia. These have taken into consideration the increasing body of knowledge obtained from neurophysiological and imaging research (eg, event-related potentials, functional MRI). The phonological deficit theory, ${ }^{32}$ which assumes a disturbance in phonological processing, is currently the most salient theory. According to this theory, affected individuals have difficulties in perceiving and segmenting phonemes, leading to difficulties in establishing a connection between phonemes and graphemes. The rapid auditory processing theory is another theory ${ }^{33}$ that proposes that phonological deficits are secondary to an auditory deficit in the perception of short or rapidly varying sounds. Many individuals with dyslexia perform poorly on auditory tasks including frequency discrimination ${ }^{3435}$ and temporal order judgement. ${ }^{36}$ Abnormal neurophysiological responses to auditory stimuli have also been reported. ${ }^{36-38}$ However, individuals with dyslexia also have visual perceptual deficits which these theories cannot adequately explain. The magnocellular theory accounts for disturbances in visual processing. ${ }^{39-42}$ The theory proposes that in a proportion of individuals with dyslexia, the perception of visual, rapid moving stimuli and stimuli of low spatial frequency and low contrast is impaired. This deficit is associated at the central nervous system (CNS) level with impaired sensitivity of cells within the retinocortical magnocellular pathway and in the extrastriate areas in the dorsal stream to which they project. The cerebellar deficit theory suggests that the automatisation of cognitive processes and motor control in the cerebellum are disturbed in individuals with dyslexia. ${ }^{43}$ The double deficit hypothesis, ${ }^{44}$ which assumes disturbances in phonological processing and the speed of processing, should also be mentioned in this context.

Even though evidence for one or the other of these theories is typically reported in affected individuals, there is no evidence so far for specific subgroups of dyslexia. A reason for this could be that although some of the deficits found in affected individuals are correlated with reading and spelling, they may not be causally associated with dyslexia. Findings from genetic research may have the potential to help delineate which cognitive and neurophysiological processes are causally related..$^{45}$

\section{LINKAGE FINDINGS IN DYSLEXIA}

To date, linkage analyses in families with dyslexia have identified nine chromosome regions (dyslexia susceptibility 1(DYXI)-dyslexia susceptibility 9 (DYX9)) listed by the HUGO Gene Nomenclature Committee in which the presence of susceptibility genes is suspected (table 2). There was initially great hope that it would be possible to correlate the respective cognitive components of dyslexia (table 1) with specific linkage regions. Many studies accordingly investigated individual phenotype components as categorical or quantitative (quantitative trait loci (QTL)) subdimensions, and linkages with specific chromosomal regions have been claimed; unfortunately, with little support from independent studies so far. Nevertheless, the consistency of linkage findings is impressive in comparison to those for other neuropsychiatric disorders. This is particularly true of findings in chromosome regions lp34-p36, 6p21-p22, 15q21 and 18q11, with support for each of these regions coming from the investigation of at least two large family samples.

The largest family samples reported in the literature are from the USA (Colorado, Seattle and Yale samples), the UK (Cardiff and Oxford samples), Canada (Toronto and Vancouver samples) and Germany (German sample). For the sake of clarity, these samples will be named according to their origin in the following sections. Results from genomewide linkage studies have been reported so far from the Seattle, ${ }^{49} 6667$ Oxford and Colorado samples..$^{53}$ In addition, genomewide linkage studies of large multiply affected families from Holland, ${ }^{65}$ Norway $^{56}$ and Finland ${ }^{58}{ }^{60}$ have been reported. The following section presents results for the individual regions, and discussion is limited to positive findings only.

\section{DYX1-chromosome 15q21}

DYX1 (MIM 127700) lies in chromosome region 15q21, and a total of four research groups have reported linkage in their family samples (table 2). ${ }^{46-48}{ }^{49}$ Evidence for linkage was found for word reading and related phenotype dimensions in three samples (Colorado, Yale and Seattle samples), ${ }^{46449}$ and one sample showed evidence of linkage for spelling (German sample) ${ }^{48}$ Two linkage disequilibrium (LD) studies have been carried out in region DYXl using short tandem repeat markers, ${ }^{68}{ }^{69}$ and positive evidence for association was obtained for one region of approximately $4 \mathrm{Mb}$. In both studies, a three-marker haplotype was associated in a total of three independent trio-samples, two samples of British origin (Cardiff sample) and one of Italian origin. ${ }^{68}{ }^{69}$ Region $15 \mathrm{q} 21$ has also shown evidence of linkage to ADHD. A genome scan carried out in 164 Dutch sib pairs with ADHD showed the strongest evidence for linkage in this region. ${ }^{70}$ The risk-conferring gene in DYXl may contribute to the comorbidity reported between the two disorders. 
Table 2 Summary of linkage findings in dyslexia

\begin{tabular}{|c|c|c|c|c|c|}
\hline Locus & Number of families (individuals, sib pairs), country & Linkage evidence & $\begin{array}{l}\text { Linkage evidence with } \\
\text { components of the } \\
\text { phenotype }\end{array}$ & Study design & References \\
\hline DYX1 & $\begin{array}{l}9 \text { multiplex families (84 individuals), USA } \\
6 \text { multiplex families (94 individuals), USA } \\
7 \text { multiplex families (67 individuals), Germany } \\
90 \text { families ( } 611 \text { individuals), USA }\end{array}$ & $\begin{array}{l}\text { LOD score } 3.20 \\
\text { LOD score } 3.15 \\
\text { LOD score } 1.78 \\
\text { LOD score } 2.34\end{array}$ & $\begin{array}{l}\text { Reading } \\
\text { Single-word reading } \\
\text { Spelling } \\
\text { Single-word reading }\end{array}$ & $\begin{array}{l}\text { Categorical } \\
\text { Categorical } \\
\text { Categorical } \\
\text { Categorical }\end{array}$ & $\begin{array}{l}\text { Smith et } a^{\mu 6} \\
\text { Grigorenko et } a{ }^{47} \\
\text { Schulte-Körne et a } a^{\mu 8} \\
\text { Chapman et } a l^{49}\end{array}$ \\
\hline \multirow[t]{5}{*}{ DYX2 } & $\begin{array}{l}19 \text { multiplex families ( } 358 \text { individuals* }{ }^{*}, 50 \\
\text { dizygotic twin-pair), USA } \\
82 \text { families ( } 181 \text { sib pairs), UK }\end{array}$ & $\begin{array}{l}p \text { Values between } \\
0.009-0.04 \\
p \text { Values between }\end{array}$ & $\begin{array}{l}\text { Dyslexia } \\
\text { Orthographic and }\end{array}$ & $\begin{array}{l}\text { QTL } \\
\text { QTL }\end{array}$ & $\begin{array}{l}\text { Cardon et } a^{50} \\
\text { Fisher et } a^{51}\end{array}$ \\
\hline & 79 families (126 sib pairs), USA & $\begin{array}{l}0.0004-0.038 \\
\text { LOD scores between } \\
2.42 \text { and } 3.10\end{array}$ & $\begin{array}{l}\text { phonological processes } \\
\text { Orthographic and } \\
\text { phonological processes }\end{array}$ & QTL & Gayan et $a^{52}$ \\
\hline & 89 families (195 sib pairs)t, UK & $\begin{array}{l}\mathrm{p} \text { Values between } \\
0.00001-0.042\end{array}$ & Phonological decoding & QTL & Fisher et $a f^{53}$ \\
\hline & 119 families (180 sib pairs) $\ddagger$, USA & $\begin{array}{l}p \text { Values between } \\
0.002-0.006\end{array}$ & Phonological decoding & & \\
\hline & 8 multiplex families (176 individuals)§ & $\begin{array}{l}\text { LOD scores of } \\
1.52 \text { and } 2.56\end{array}$ & $\begin{array}{l}\text { Single-word reading, } \\
\text { phoneme awareness }\end{array}$ & Categorical & Grigorenko et $\left.a\right|^{55}$ \\
\hline \multirow[t]{3}{*}{ DYX3 } & $\begin{array}{l}1 \text { multiplex family ( } 36 \text { individuals), Norway } \\
89 \text { families ( } 195 \text { sib pairs), UK } \\
119 \text { families (180 sib pairs), USA }\end{array}$ & $\begin{array}{l}\text { LOD score } 4.32 \\
p \text { Value }<0.001 \\
p \text { Value of } 0.001\end{array}$ & $\begin{array}{l}\text { Dyslexia } \\
\text { Orthographic choice } \\
\text { Phonological } \\
\text { awareness }\end{array}$ & $\begin{array}{l}\text { Categorical } \\
\text { QTL } \\
\text { QTL }\end{array}$ & $\begin{array}{l}\text { Fagerheim et } a f^{56} \\
\text { Fisher et }\left.a\right|^{53}\end{array}$ \\
\hline & 96 families (877 individuals), Canada & $\begin{array}{l}\text { LOD scores of } \\
1.13 \text { and } 3.82\end{array}$ & $\begin{array}{l}\text { Phonological coding, } \\
\text { spelling }\end{array}$ & QTL and categorical & Petryshen et $a^{57}$ \\
\hline & 11 multiplex families (97 individuals), Finland & LOD score 3.01 & Dyslexia & Categarical & Kaminen et $a^{58}$ \\
\hline DYX4 & 96 families (877 individuals), Canada & $\begin{array}{l}\text { LOD scores of } \\
2.08 \text { and } 3.34\end{array}$ & $\begin{array}{l}\text { Phonological coding, } \\
\text { spelling }\end{array}$ & QTL and categorical & Petryshen et $a P^{59}$ \\
\hline DYX5 & 1 multiplex family (74 individuals), Finland & LOD score 3.84 & Dyslexia & Categorical & Nopola-Hemmi et $a l^{\beta 0}$ \\
\hline DYX6 & $\begin{array}{l}89 \text { families (195 sib pairs), UK } \\
119 \text { families (180 sib pairs), USA } \\
84 \text { families (143 sib pairs), UK }\end{array}$ & $\begin{array}{l}\mathrm{p} \text { Value }<0.001 \\
\mathrm{p} \text { Value }<0.001 \\
\mathrm{p} \text { Value }<0.001\end{array}$ & $\begin{array}{l}\text { Single-word reading } \\
\text { Single-word reading } \\
\text { Phoneme awareness }\end{array}$ & $\begin{array}{l}\text { QTL } \\
\text { QTL } \\
\text { QTL }\end{array}$ & Fisher et $a f^{53}$ \\
\hline DYX7 & 100 families (914 individuals), Canada & $\mathrm{p}$ Value $<0.001$ & Dyslexia & Categorical & Hsiung et $\left.a\right|^{\beta 1}$ \\
\hline \multirow[t]{3}{*}{ DYX8 } & 9 families, USA & $\begin{array}{l}\text { LOD score of } \\
1.95 \text { and } 2.33\end{array}$ & Dyslexia & QTL & Rabin et $\left.a\right|^{62}$ \\
\hline & 8 multiplex families (165 individuals), USA & $\begin{array}{l}\text { LOD scores of } \\
3.00 \text { and } 2.30\end{array}$ & $\begin{array}{l}\text { Single-word reading, } \\
\text { phonological decoding }\end{array}$ & Categorical & \\
\hline & 100 families (914 individuals), Canada & $\begin{array}{l}\text { LOD scores of } \\
4.01 \text { and } 1.65\end{array}$ & $\begin{array}{l}\text { Spelling, phonological } \\
\text { coding }\end{array}$ & QTL and categorical & Tzenova et $\left.a\right|^{1 / 4}$ \\
\hline DYX9 & $\begin{array}{l}1 \text { multiplex family ( } 29 \text { individuals), Netherlands } \\
89 \text { families (195 sib pairs), UK }\end{array}$ & $\begin{array}{l}\text { LOD score } 3.68 \\
p \text { Value of } 0.001\end{array}$ & $\begin{array}{l}\text { Dyslexia } \\
\text { Single-word reading }\end{array}$ & $\begin{array}{l}\text { Categorical } \\
\text { QTL }\end{array}$ & $\begin{array}{l}\text { de Kovel et al } \\
\text { Fisher et al }\end{array}$ \\
\hline \multicolumn{6}{|c|}{$\begin{array}{l}\text { LOD, logarithm of the odds; QTL, quantitative trait loci. } \\
\text { *Including } 18 \text { families with linkage evidence at DYX2 previously reported by Smith et al. }{ }^{46} \\
\text { tIncluding } 82 \text { families with linkage evidence at DYX2 previously reported by Fisher et al. }{ }^{51} \\
\text { fIncluding } 39 \text { families with linkage evidence at DYX } 2 \text { previously reported by Cardon et al }{ }^{50} \text { and } 70 \text { families with linkage evidence at DYX } 2 \text { previously reported by Gayan } \\
\text { et al. }{ }^{52} \\
\text { §Including } 8 \text { families with linkage evidence at DYX2 previously reported by Grigorenko et al. }{ }^{4755}\end{array}$} \\
\hline
\end{tabular}

\section{DYX2 - chromosome 6p21-p22}

The chromosome region 6p2l-p22 (DYX2, MIM 600202) is considered to be among the best-replicated regions of linkage for dyslexia (table 2). Evidence of linkage has been reported using a QTL approach in both a US-American (Colorado) and a UK (Oxford) sample. ${ }^{53}{ }^{50-52}{ }^{54}$ Positive evidence for linkage was also reported from a US-American subsample (Yale sample) in which categorical phenotype dimensions had been considered. ${ }^{55}$ A more precise containment of the phenotype subdimensions associated with DYX2 was not possible. Linkage was found with the phenotypes phonological processing ${ }^{51-54}$ and orthographic processing. ${ }^{51525455}$ Meanwhile, LD mapping in DYX2 led to the identification of two strong candidate genes ( $D C D C 2$ (doublecortin domain containing protein 2) and KlAA0319). ${ }^{71-75}$ Interestingly, evidence for linkage has also been found in the chromosome region 6p21-p22 for ADHD. ${ }^{76}$

\section{DYX3-chromosome 2p15-p 16}

The chromosome region 2p15-pl6 (DYX3, MIM 604254) has been identified through linkage analyses in five family samples (including the Oxford, Colorado and Vancouver samples; table 2)..$^{53}$ 56-58 77 The linkage peaks of the individual studies lie far apart from each other, however, and so it is not clear whether they indicate the same susceptibility locus. As with DYX2, no phenotype dimension has been found to be specifically linked with this locus, although not all studies have analysed subdimensions.

\section{DYX4-chromosome 6q11-q12}

The chromosome region 6ql1-q12 (DYX4, MIM 127700) was identified in the context of a chromosome-wide linkage study of a large Canadian family sample (Vancouver sample; table 2). ${ }^{59}$ The most strongly linked phenotype dimensions 
were phonological coding and spelling. There has so far been no independent replication of this finding for DYX4.

\section{DYX5-chromosome 3p12-q13}

The chromosome region 3p12-q13 (DYX5, MIM 606 896) showed linkage in a large Finnish family (table 2) ${ }^{60} \mathrm{ROBOI}$ (roundabout Drosophila homolog of 1 ) has been identified as a possible candidate gene in this region. DYX5 also showed a positive evidence for linkage in 77 US-American families with speech-sound disorder (SSD). ${ }^{78}$ SSD involves impairments in phonological processing, as with dyslexia.

\section{DYX6-chromosome 18p11}

DYX6 (MIM 606616), which lies in chromosome region 18pll, was identified in two independent family samples (Oxford and Colorado samples) through a genome scan applying a QTL approach (table 2). ${ }^{53}$ The strongest evidence for linkage was found for word reading. This finding was replicated in a third family sample (expanded Oxford sample), the strongest evidence for linkage being found for the phenotype subdimension phoneme awareness. ${ }^{53}$ The results of a subsequent multivariate analysis in the two Oxford samples indicate that a QTL in DYX6 influences multiple aspects of reading ability and is not correlated with specific phenotype subdimensions. ${ }^{79}$

\section{DYX7-chromosome 11 p 15}

Linkage with markers in the region of DYX7 (MIM 127700), which lies in chromosome region $11 \mathrm{pl} 5$, has been described only in one family sample to date (Vancouver sample; table 2) ${ }^{61}$ The authors selected DYX7 as a candidate region on the basis that the gene for the dopamine $\mathrm{D} 4$ receptor $(D R D 4)$ is localised there. DRD4 is a possible risk gene for ADHD. ${ }^{80}$

\section{DYX8-chromosome 1p34-1p36}

Three research groups in total have reported linkage between DYX8 (MIM 608995) in chromosome region 1p34-p36 and dyslexia (including the Yale and Vancouver samples; table 2). ${ }^{62-64}$ Even though individual studies have shown linkage to differing phenotype subdimensions of dyslexia, linkage evidence from two studies was particularly strong when focus was placed on the phonological aspects of dyslexia. ${ }^{63} 64$

\section{DYX9-chromosome Xq26-q27}

Evidence for linkage was found in chromosome region Xq27 (DYX9, MIM 300509) in a Dutch multiplex family with dyslexia (table 2). ${ }^{65}$ The same research group failed to replicate their result in 67 affected sib pairs. However, positive evidence for linkage was found in region DYX9 in one of the UK samples (Oxford sample; table 2). ${ }^{53}$

\section{Additional linkage regions in dyslexia}

In addition to the HGNC-listed DYXI-DYX9 regions, linkage with dyslexia has also been reported for other regions, although without replication in independent samples. This includes evidence for linkage on chromosome $13 \mathrm{q} 12$ for word reading, ${ }^{66}$ and on chromosome 2q22 for phonological decoding efficiency. ${ }^{67}$ Two further studies have been conducted which aimed to identify chromosomal loci with pleiotropic effects on dyslexia and ADHD. In the Colorado sample, families with dyslexia having ADHD problems showed evidence for linkage in chromosome regions $14 \mathrm{q} 32,13 \mathrm{q} 32$ and $20 \mathrm{ql} 1 .^{81}$ In families with ADHD, evidence for linkage is shown for reading ability in regions $10 \mathrm{q} 11,16 \mathrm{p} 12$ and $17 \mathrm{q} 22 .{ }^{82}$

\section{CANDIDATE GENE FINDINGS IN DYSLEXIA}

Of the newly identified candidate genes, DCDC2 and K1AA0319 seem to be of most significance for dyslexia. Both were identified through systematic investigation of LD (LD mapping) within DYX2 on chromosome 6p22. Initial findings for both genes have been replicated in independent samples, with the strongest findings being reported among severely affected individuals. By contrast, the genes DYXICl (dyslexia susceptibility l candidate 1) and ROBOl, which were identified through breakpoint mapping in Finnish patients, seem to be less involved in the development of dyslexia across different populations. Their contribution may be limited to a few families in the Finnish population.

\section{DCDC2 (doublecortin domain containing protein 2)}

Initial evidence for the involvement of DCDC2 (MIM 605755) and dyslexia was obtained through gene-based LD mapping in a gene-dense $680 \mathrm{~kb}$ section of linkage region 6p22 (DXY2; table 3). ${ }^{72}$ The sample was drawn from 114 US-American nuclear families of predominantly European origin (Colorado sample). Positive evidence for association was found in two genome loci, in which a total of six genes were localised: $V M P$ / DCDC2/KAAG1 and K1AA0319/TTRAP/THEM2. In a subsequently expanded Colorado sample (153 nuclear families), the strongest evidence for association was found in $D C D C 2$ (table 3). ${ }^{74}$ Additionally, a deletion of $2.4 \mathrm{~kb}$ in intron 2 of $D C D C 2$, which encodes tandem repeats of putative brain-associated transcription factor binding sites, was identified, which had an allele frequency of $8.5 \%$ in the parents. ${ }^{74}$ The tandem repeats in the deleted region demonstrate several alleles. For the purposes of the association study, the authors combined the deletion and the rare repeat alleles into one allele, for which they reported a strong association with reading performance.

Findings from two trio-samples also indicate the involvement of $D C D C 2$ in the development of dyslexia (German sample; table 3). ${ }^{75}$ Strong evidence for association was shown in both samples at the single-marker and haplotype level. This effect seemed to be particularly substantial in severely affected individuals. In the pooled sample, severely affected individuals showed a genotypic relative risk of 4.88 on the basis of the homozygous presence of the identified risk haplotype.

By contrast, investigation of the $D C D C 2$ locus in the two UK samples (Oxford and Cardiff) had inconsistent results. In the Oxford sample, evidence of association between $D C D C 2$ variants and various phenotype components of dyslexia were found, albeit with a weak level of significance. This association disappeared, however, when only severely affected cases were included in the analysis. Interestingly, the $2.4 \mathrm{~kb}$ deletion in intron 2 of $D C D C 2$ was more common than by chance in severely affected patients. There was no association between dyslexia and DCDC2 in the Cardiff sample. Joint analysis of the two samples, however, produced evidence of a possible interaction between $D C D C 2$ and K1AA0319. ${ }^{90}$

In summary, these results suggest that $D C D C 2$ is involved in the development of dyslexia. It is unlikely that KAAG1 is the susceptibility gene at this locus. KAAGI overlaps at the genomic level with exon 1 of $D C D C 2$, although KAAG1 does not seem to be expressed in the CNS. ${ }^{74}$ By contrast, $D C D C 2$ is widely expressed in the CNS, including areas of the brain in which lower activation patterns have been observed in individuals with dyslexia, such as the inferior temporal and medial temporal cortices. ${ }^{74}{ }^{75}$ 91-93

Functionally, DCDC2 is involved in processes of cortical neuronal migration during brain development and contains a double cortin homology domain which is typical of this. RNA interference studies of in utero rats have shown that downregulation of DCDC2 leads to a significant reduction in neuronal migration. ${ }^{74}$ Determining whether the intron 2 deletion is one of the responsible variants will require further investigation in larger samples. There is no real rationale for combining the deletion with rare alleles of the STR polymorphism. Functional studies of the possible effect of the different 
Table 3 Summary of association findings in dyslexia

\begin{tabular}{|c|c|c|c|c|c|}
\hline Gene & Study design & $\begin{array}{l}\text { Sample characteristics, } \\
\text { country }\end{array}$ & Genotyped variants & Results & References \\
\hline \multirow[t]{8}{*}{ DYX1Cl } & Case-control & $\begin{array}{l}55 \text { cases* vs } 113 \text { controls, }^{\text {Finland }}\end{array}$ & 8 SNPs & $\begin{array}{l}\text { Significant association at the single-marker and } \\
\text { haplotype level }\end{array}$ & Taipale et $a^{\beta 3}$ \\
\hline & Case-control & $\begin{array}{l}54 \text { cases* vs } 82 \text { controls, } \\
\text { Finland }\end{array}$ & $8 \mathrm{SNPs} \dagger$ & Significant association at the single-marker level & \\
\hline & Family based & $\begin{array}{l}148 \text { nuclear families, } \\
\text { Canada }\end{array}$ & 6 SNPst & $\begin{array}{l}\text { Significant association at the single-marker and } \\
\text { haplotype level, association in the opposite } \\
\text { direction compared to Taipale et } a^{\beta 3}\end{array}$ & Wigg et $a l^{\beta 4}$ \\
\hline & Family based & 264 nuclear families, UK & 8 SNPs† & $\begin{array}{l}\text { Significant association at the single-marker level, } \\
\text { association in the opposite direction compared } \\
\text { to Taipale et } a^{\beta 3}\end{array}$ & Scerri et $\left.a\right|^{\beta 5}$ \\
\hline & Family based & 150 nuclear families, USA & 2 SNPs† & No association & Meng et $a^{\beta 6}$ \\
\hline & Family based & 158 nuclear families, Italy & 3 SNPs† & No association & Marino et $a^{\beta 7}$ \\
\hline & Case-control & 57 cases vs 96 controls, Italy & 3 SNPs† & No association & Bellini et $a^{\beta 8}$ \\
\hline & Family based & 247 nuclear families, UK & 3 SNPs† & No association & Cope et $a^{\beta 9}$ \\
\hline \multirow[t]{5}{*}{$D C D C 2$} & Family based & 114 nuclear families, USA & $\begin{array}{l}31 \text { SNPs within } 680 \mathrm{~kb} \\
\text { (including VMP, DCDC2, } \\
\text { KAAG1, KIAAO319, } \\
\text { TTRAP and THEM2) }\end{array}$ & $\begin{array}{l}\text { Strongest association at the single-marker and } \\
\text { haplotype level within the VMP/DCDC2/KAAG1 } \\
\text { locus }\end{array}$ & $\begin{array}{l}\text { Deffenbacher } \\
\text { et } a f^{2}\end{array}$ \\
\hline & Family based & 153 nuclear families, USA & $\begin{array}{l}147 \text { SNPs within } 1.5 \mathrm{Mb} \\
\text { (including VMP, DCDC2, } \\
\text { KAAG1, KIAAO319, } \\
\text { TTRAP and THEM2) }\end{array}$ & $\begin{array}{l}\text { Strongest association at the single-marker and } \\
\text { haplotype level within DCDC2 }\end{array}$ & Meng et $a P^{4}$ \\
\hline & Case-control & $\begin{array}{l}240 \text { cases vs } 312 \text { controls, } \\
\text { UK } \ddagger\end{array}$ & $\begin{array}{l}137 \text { SNPs within VMP, } \\
\text { DCDC2, KAAG1, } \\
\text { KIAA0319, TTRAP and } \\
\text { THEM2 }\end{array}$ & $\begin{array}{l}\text { No association within the VMP/DCDC2/KAAG1 } \\
\text { locus }\end{array}$ & Cope et $a P^{1}$ \\
\hline & Family based & 137 triads, Germany & $\begin{array}{l}18 \mathrm{SNPs} \text { and } 4 \text { STRs } \\
\text { within the VMP/DCDC2/ } \\
\text { KAAG1-locus }\end{array}$ & $\begin{array}{l}\text { Strongest association at the single-marker and } \\
\text { haplotype level within } D C D C 2 \text {, strongest results } \\
\text { with severity selection }\end{array}$ & $\begin{array}{l}\text { Schumacher et } \\
a P^{5}\end{array}$ \\
\hline & Family based & 239 triads, Germany & $\begin{array}{l}2 \text { SNPs, } 1 \text { STR within } \\
\text { DCDC2 }\end{array}$ & $\begin{array}{l}\text { Significant association at the haplotype level, } \\
\text { strongest results with severity selection }\end{array}$ & \\
\hline \multirow[t]{10}{*}{ KIAA0319 } & Family based & 114 nuclear families, USA & $\begin{array}{l}31 \mathrm{SNPs} \text { within } 680 \mathrm{~kb} \\
\text { (including VMP, DCDC2, } \\
\text { KAAG1, KIAAO319, } \\
\text { TTRAP and THEM2) }\end{array}$ & $\begin{array}{l}\text { Significant association at the single-marker and } \\
\text { haplotype level within the KIAA0319/TTRAP/ } \\
\text { THEM2 locus }\end{array}$ & $\begin{array}{l}\text { Deffenbacher } \\
\text { et } a f^{2}\end{array}$ \\
\hline & Family based & 42 nuclear families, UK§ & $\begin{array}{l}31 \text { SNPs within } 680 \mathrm{~kb} \\
\text { (including the } \\
\text { KIAA0319/TTRAP/ } \\
\text { THEM2 locus) }\end{array}$ & $\begin{array}{l}\text { Strongest association at the single-marker and } \\
\text { haplotype level within KIAAO319 and TTRAP }\end{array}$ & Francks et $a P^{3}$ \\
\hline & Family based & 84 nuclear families, UK§ & $\begin{array}{l}20 \text { SNPs within } \\
\text { KIAA0319 and TTRAP }\end{array}$ & $\begin{array}{l}\text { Significant association at the single-marker and } \\
\text { haplotype level }\end{array}$ & \\
\hline & Family based & 124 nuclear families, USA§ & $\begin{array}{l}21 \text { SNPs within } \\
\text { KIAA0319 and TTRAP }\end{array}$ & $\begin{array}{l}\text { Significant association at the single-marker and } \\
\text { haplotype level }\end{array}$ & Cope et $a P^{1}$ \\
\hline & Case- control & $\begin{array}{l}240 \text { cases vs } 312 \text { controls, } \\
\text { UK } ₫\end{array}$ & $\begin{array}{l}137 \text { SNPs within VMP, } \\
\text { DCDC2, KAAG1, } \\
\text { KIAA0319, TTRAP and } \\
\text { THEM2 }\end{array}$ & $\begin{array}{l}\text { Strongest association at the single-marker and } \\
\text { haplotype level within KIAAO319 }\end{array}$ & \\
\hline & Case-control & $\begin{array}{l}223 \text { cases vs } 273 \text { controls, } \\
\text { UK } ₫\end{array}$ & $\begin{array}{l}10 \text { SNPs within the } \\
\text { KIAAO319/TTRAP/ } \\
\text { THEM2-locus }\end{array}$ & $\begin{array}{l}\text { Strongest association at the single-marker and } \\
\text { haplotype level within KIAAO319 }\end{array}$ & $\begin{array}{l}\text { Schumacher et } \\
a f^{5}\end{array}$ \\
\hline & Family based & 376 triads, Germany & $\begin{array}{l}10 \text { SNPs within the } \\
\text { KIAA0319/TTRAP/ } \\
\text { THEM2 locus }\end{array}$ & $\begin{array}{l}\text { Nominal significant association at the single- } \\
\text { marker level for } 1 \text { variant within KIAA0319 in } \\
\text { the most severely affected subsample }\end{array}$ & Harold et apo \\
\hline & Family based & 126 nuclear families, UK§ & $\begin{array}{l}16 \text { SNPs within DCDC2, } \\
\text { KIAAO319 and flanking } \\
\text { region }\end{array}$ & $\begin{array}{l}\text { Strongest association at the single-marker level } \\
\text { within } 20 \mathrm{kB} \text { in intron 1 of KIAAO319 }\end{array}$ & \\
\hline & Case-control & $\begin{array}{l}350 \text { cases vs } 273 \text { controls, } \\
\text { UK }\end{array}$ & $\begin{array}{l}28 \text { SNPs and } 1 \text { STR within } \\
\text { DCDC2, KIAAO } 319 \text { and } \\
\text { flanking regions }\end{array}$ & $\begin{array}{l}\text { Evidence for gene-gene interaction between } \\
\text { KIAA0319 and DCDC2 }\end{array}$ & \\
\hline & Case-control & $\begin{array}{l}419 \text { cases vs } 273 \text { controls, } \\
\text { UK }\end{array}$ & $\begin{array}{l}4 \text { SNPs and } 1 \text { STR within } \\
\text { DCDC2 and } 5 \text { SNPS } \\
\text { within KIAA0319 }\end{array}$ & & \\
\hline
\end{tabular}

$D C D C 2$, doublecortin domain containing protein 2gene; SNP, single-nucleotide polymorphism.

*Some cases were extracted from the same families and are related.

tIncluding the two significantly associated SNPs reported by Taipale et al. ${ }^{83}$

¥Cases and controls were analysed using a DNA pooling approach.

$\S$ Samples represent subsamples selected for severity of the phenotype.

- Individual genotyping of markers that were associated in the pooled samples (most of the cases and controls are identical).

alleles on expression or splicing are required to justify the combining of alleles.

\section{KIAA0319}

Besides evidence for association in the region of $D C D C 2$, positive association with variants in the region of the K1AA0319/TTRAP/
THEM2 gene cluster (MIM 609269) was reported in the Colorado sample. ${ }^{72}$ Association for the same gene cluster was reported by Francks et al in two independent samples (Oxford samples), which was particularly notable in severely affected individuals (table 3 ). ${ }^{73}$ Association in this region was replicated in a third UK sample (Cardiff sample; table 3). ${ }^{71}$ There was an 
association with SNPs in the region of KIAA0319 through the use of a DNA pooling screening step and subsequent replication through individual genotyping.

Meanwhile, further analyses of the two samples (Oxford and Cardiff) have shown that the responsible gene variant(s) is (are) probably localised near exon 1 of K1AA0319. Investigation of both UK samples has resulted in evidence of a gene-gene interaction between KIAA0319 and DCDC2. ${ }^{90}$

One sample (German sample), which had reported strong association with $D C D C 2$, has so far produced no convincing evidence for association with the KIAA0319/TTRAP/THEM2 gene cluster. ${ }^{75}$ There was no further evidence of association at the KlAA0319 locus from the extended Colorado sample (153 nuclear families), ${ }^{74}$ although the genomic segment that had shown the strongest association findings in the two UK samples was insufficiently analysed.

The evidence of association for KlAA0319 obtained from independent samples is convincing. As with $D C D C 2$, involvement of the KIAA0319 locus seems to be particularly marked in severely affected cases. Association findings, which were strongest around KIAA0319, and results from gene expression and functional studies suggest that KIAA0319 is the most likely susceptibility gene for dyslexia in this gene cluster. Allelespecific expression analyses in lymphoblastoid cells have shown that carriers of the risk-associated haplotype have a $40 \%$ reduction in the expression of KIAA0319, whereas the expression of other genes in this region remains unaffected. ${ }^{94}$ The expression of KIAA0319 is particularly strong in the cerebral neocortex of developing mouse and human brain tissue, and, similar to DCDC2, reduced expression of KIAA0319 through RNA interference leads to disturbed neuronal migration in rats in utero. ${ }^{94}$

\section{DYX $1 C 1$}

DYXICI (MIM 608706) was cloned in a two-generation Finnish family with a translocation $\mathrm{t}(2 ; 15)(\mathrm{ql} 1 ; \mathrm{q} 21) .{ }^{83} \mathrm{DYXICl}$, which lies in chromosome region $15 \mathrm{q} 21$, is interrupted through the translocation breakpoint. All four family members in whom the translocation was detected showed reading-associated problems. ${ }^{95}$ To determine whether DYXICl is of significance for affected cases outside of this family, a polymorphism discovery approach was used in 20 Finnish individuals with dyslexia. A total of eight SNPs were identified, which were then investigated in affected individuals and controls of Finnish origin. In an initial sample, two SNPs were found to be associated in the single-marker and haplotype analysis. Replication was then achieved for one of the two variants in a second sample (table 3 ). However, the sample sizes were limited, and a proportion of the affected individuals in the initial sample were related to each other. ${ }^{83}$

DYXICl is expressed in many tissues, including those of the CNS, where it is found in cortical neurones and white matter glial cells. ${ }^{83}$ Interestingly, it has recently been shown that DYX1C1, similar to KIAA0319 and DCDC2, functions in neuronal migration in rodent neocortex. ${ }^{96}$

Six other association analyses using independent samples of predominantly European origin have been carried out to date (including the Oxford, Cardiff, Colorado and Toronto samples) ${ }^{84-89}$ Overall, the results must be viewed as being negative, since the initial findings have not been replicated. Positive findings have been reported from two of these studies, although the association was with the opposite two-marker haplotype (Oxford and Toronto samples; table 3). ${ }^{84}{ }^{85}$ Given this failure to replicate, it is unlikely that DYXICl makes a significant contribution to the development of dyslexia in non-Finnish European populations.

It is highly probable that the linkage findings in chromosome region 15q21 (DYX1) cannot be traced back to DYXICl, since
DYXICl lies outside of the linkage peaks. Whether or not DYXICl contributes to dyslexia in the Finnish population requires clarification through larger association studies.

\section{ROBOI}

As with DYXICl, the identification of ROBOI (MIM 602430) was achieved through breakpoint mapping of a translocation. A translocation, which had probably occurred de novo, was diagnosed in an affected individual from Finland $\mathrm{t}(3 ; 8)(\mathrm{pl} 2: \mathrm{ql} 1) \cdot{ }^{97} \mathrm{ROBOl}$ was interrupted through the translocation breakpoint, localised in linkage region 3pl2 (DYX5). A rare $R O B O 1$ haplotype was identified in the Finnish family, in which the original linkage finding for DYX5 had been found, and cosegregation of this haplotype with dyslexia was reported. Lymphocyte investigation of four affected family members showed that expression of the risk haploytpe was reduced. ${ }^{97}$ Investigation of the orthologous gene in Drosophila (robo) and mice (Robol) suggests that $\mathrm{ROBOl}$ functions as a neuronal axon guidance gene involved in brain development. ${ }^{98-100}$

Whether or not ROBOI actually contributes to the development of dyslexia is currently not clear. A critical point is that the connection between the translocation and dyslexia in the original translocation patient was not imperative: A sibling of the translocation carrier also had dyslexia without carrying the translocation. Should the dyslexia of the Finnish multiplex family be based on a rare and highly penetrant mutation, the causal variant will not be easy to identify, given its size (990 kb of genomic DNA) and the difficulties involved in separating the effects of individual variants from the background variation characterising the haplotype.

\section{CONCLUSIONS}

Of the candidate genes discussed to date, the evidence for DCDC2 and KIAA0319 is the most convincing. Their identification represents an important step in our understanding of the molecular processes that lead to dyslexia. However, many outstanding questions will need to be addressed by future studies. It is necessary to clarify whether populationspecific genetic heterogeneity and/or phenotypic differences between samples have led to differing findings for the respective loci. Identifying which of the genetic changes in these candidate genes are causal is also important. The lack of associated variants in the coding regions suggests that it is variants influencing generegulation and expression which are responsible.

The nature of the genes identified to date suggests that a disturbance in cortical neurone migration and reduced activity in left-hemispheric brain regions are pathophysiological correlates of dyslexia. With DCDC2, as with KIAA0319, inhibition leads to poorer neuronal migration in the neocortex of fetal rats through specific small interfering RNAs. ${ }^{74}$ This concept of disturbed neuronal migration is also supported by the few results available from postmortem brain studies of affected individuals, which report cortical malformations in the region of the perisylvian cortex. ${ }^{101-103}$ The concept of disturbed neuronal migration in dyslexia is intriguing and will stimulate further research in this area. In view of the fact that $D C D C 2$ and KlAA0319 only contribute a limited part to the development of dyslexia and that most susceptibility genes are still unknown, it may be possible in the future to identify completely new pathophysiological mechanisms.

To date, no specific cognitive processes are known to be influenced by the proposed susceptibility genes. Some studies have already started to include neurophysiological (eg, eventrelated potential) and imaging (eg, functional MRI) procedures in their phenotype characterisation of patients. Such samples are an important prerequisite for the identification of those 
processes that are most proximal to the effects of particular genes and their associated biological pathways.

Through the availability of detailed clinical data, it should be possible to associate special phenotype dimensions of dyslexia with specific risk genes (genotype-phenotype association). Phenotype subdimensions are, of course, correlated with each other, and the effects will not affect isolated subdimensions. Nor is it to be expected that specific genes will affect the whole spectrum of phenotype dimensions equally. Studies have not yet managed to establish genotype-phenotype relations convincingly, although samples may have been too small to demonstrate these effects. However, proof of genotype-phenotype associations could be facilitated through the joint analysis of larger samples and the identification of causative variants.

The molecular genetic studies conducted so far have not considered sex-specific genetic effects. Differing prevalence rates between males and females could be suggestive of a sexspecific geneeffect. A satisfactory power to detect such effects can be provided only when sex is taken into account during the analysis of results, ${ }^{66}$ and this should be a feature of future studies.

Identification of susceptibility genes will allow research into the molecular background of clinically observed comorbidity. Eight loci have already been proposed as having pleiotropic effects on dyslexia and ADHD at a linkage level. ${ }^{46-54} 70768182$ The identification of susceptibility genes also allows examination of the extent to which dyslexia-associated disorders, such as SSD and language impairment, are influenced by the same susceptibility genes. For SSD, overlapping linkage evidence in DYX5 already provides the first concrete evidence of such common gene effects. ${ }^{6078}$

The identification of susceptibility genes will enable the analysis of gene-gene interactions, through which epistatic effects can be discovered. A first example of this might be the proposed interaction between $D C D C 2$ and KIAA0319..$^{90}$ A further aim of future research will be to establish a better understanding of gene-environment interactions in order to identify relevant exogenous risk factors. It has long been recognised that environmental factors are of great relevance to the development of dyslexia, but only some of these factors have been identified so far. ${ }^{104}$ If such factors can be modulated, future dyslexia prevention and individual genetic risk profiling could be envisaged.

The genes that accompany the development of dyslexia are naturally of great interest from an evolutionary perspective. ${ }^{105}$ Through the identification of the gene at the DNA level, comparison with species that are closely related to us but that do not have the same speech capacity could be carried out, as well as examination of sequence variability between humans. Speech-associated genes may have been under a selection pressure, which proved advantageous for the development of modern man.

As is generally the case with research on complex genetic disorders, it can be assumed that the speed by which susceptibility genes are identified will be increased through increasing knowledge and huge technological advances (eg, genomewide association studies). Future research efforts will be of a collaborative nature, drawing on complementary expertise from various scientific disciplines and involving the combining of large samples, an approach exemplified by the large multidisciplinary European research consortium (www.neurodys.com) which integrates the work of research groups from nine countries.

\footnotetext{
Authors' affiliations

Johannes Schumacher, Institute of Human Genetics, University of Bonn, Bonn, Germany
}

Per Hoffmann, Markus M Nöthen, Department of Genomics, Life \& Brain Centre, University of Bonn, Bonn, Germany

Christine Schmäl, Division of Genetic Epidemiology in Psychiatry, Central Institute of Mental Health, Mannheim, Germany

Gerd Schulte-Körne, Department of Child and Adolescent Psychiatry, Psychotherapy and Psychosomatic Medicine, University of Munich, Munich, Germany

Funding: This work was supported by the Deutsche Forschungsgemeinschaft. Competing interests: None.

\section{REFERENCES}

1 Katusic SK, Colligan RC, Barbaresi WJ, et al. Incidence of reading disability in a population-based birth cohort, 1976-1982, Rochester, Minn. Mayo Clin Proc 2001;76:1081-92.

2 Shaywitz SE, Shaywitz BA, Fletcher JM, et al. Prevalence of reading-disability in boys and girls - results of the Connecticut longitudinal-study. JAMA 1990;264:998-1002.

3 World Health Organization. The ICD-10 classification of mental and behavioural disorders: diagnostic criteria for research. Geneva: World Health Organization, 1993.

4 Shaywitz SE, Fletcher JM, Holahan JM, et al. Persistence of dyslexia: the Connecticut Longitudinal Study at adolescence. Pediatrics 1999;104:1351-9.

5 Bruck M. Outcomes of adults with childhood histories of dyslexia. In: Hulme C, Joshi RM, eds. Reading and spelling:development and disorders. Mahwah, NJ: L Erlbaum, 1998:179-200.

6 Maughan B. Annotation: long-term outcomes of developmental reading problems. J Child Psychol Psychiatry 1995;36:357-71.

7 Strehlow U, Kluge R, Möller $\mathrm{H}$, et al. Long-term course of dyslexia beyond the school years: catamnesis from pediatric psychiatric ambulatory care. Z Kinder Jugend psychiatr 1992;20:254-65

8 August GJ, Garfinkel BD. Comorbidity of ADHD and reading disability among clinic-referred children. J Abnorm Child Psychol 1990;18:29-45.

9 Kaplan BJ, Dewey DM, Crawford SG, et al. The term comorbidity is of questionable value in reference to developmental disorders: data and theory. J Learn Disabil 2001;34:555-65.

10 Purvis KL, Tannock R. Language abilities in children with attention deficit hyperactivity disorder, reading disabilities, and normal controls. J Abnorm Child Psychol 1997;25:133-44.

11 Shaywitz SE. Dyslexia. N Engl J Med 1998;338:307-12.

12 Willcutt EG, Pennington BF, DeFries JC. Twin study of the etiology of comorbidity between reading disability and attention-deficit/hyperactivity disorder. Am J Med Genet 2000;96:293-301.

13 Fravenheim JG, Heckerl JR. A longitudinal study of psychological and achievement test performance in severe dyslexic adults. J Learn Disabil 1983; 16:339-47.

14 Naylor CF, Felton RH, Wood FB. Adult outcome in developmental dyslexia. In: Pavlidis G, eds. Perspectives on dyslexia:cognition, language and treatment. Vol 2. Chichester, England: John Wiley \& Sons, 1990:29.

15 Schulte-Körne G, Deimel W, Remschmidt H. Diagnosis of reading and spelling disorder. Z Kinder Jugendpsychiatr Psychother 2001;29:113-16.

16 Rutter M, Caspi A, Fergusson D, et al. Sex differences in developmental reading disability - new findings from 4 epidemiological studies. JAMA 2004;291:2007-12.

17 Olson RK. Dyslexia: nature and nurture. Dyslexia 2002;8:143-59.

18 Hinshelwood J. Word-blindness and visual memory. Lancet 1895; 146:1564-70.

19 Stephenson S. Six cases of congenital word-blindness affecting three generations of one family. Ophthalmoscope 1907;5:482-4.

20 Thomas $\mathrm{CJ}$. Congenital word blindness and its treatment. Ophthalmoscope 1905;3:380-5

21 Hallgren B. Specific dyslexia (congenital word-blindness); a clinical and genetic study. Acta Neurol Scand (Suppl), 1950;65:1-287.

22 Olson RK, Forsberg H, Wise B. Genes, environment, and development of orthographic skills. In: Berninger WW, eds. The varieties of orthographic knowledge l:theoretical and developmental issues. Dordrecht, Netherlands: Kluwer Academic Publishers, 1994:27-71.

23 Schulte-Körne G, Deimel W, Müller K, et al. Familial aggregation of spelling disability. J Child Psychol Psychiatry 1996;37:817-22.

24 Stevenson J. Which aspects of processing text mediate genetic-effects. Read Writ 1991;3:249-69.

25 Ziegler A, König IR, Deimel W, et al. Developmental dyslexia-recurrence risk estimates from a German bi-center study using the single proband sib pair design. Hum Hered 2005;59:136-43.

26 Plomin R, Kovas Y. Generalist genes and learning disabilities. Psychol Bull 2005; 131:592-617.

27 Gayán J, Olson RK. Genetic and environmental influences on orthographic and phonological skills in children with reading disabilities. Dev Neuropsychol 2001;20:483-507.

28 Hawke JL, Wadsworth SJ, DeFries JC. Genetic influences on reading difficulties in boys and girls: the Colorado twin study. Dyslexia 2006;12:21-9.

29 Wadsworth SJ, Knopik VS, DeFries JC. Reading disability in boys and girls: no evidence for a differential genetic etiology. Read Writ 2000;13:133-45. 
30 Harlaar N, Spinath FM, Dale PS, et al. Genetic influences on early word recognition abilities and disabilities: a study of 7-year-old twins. J Child Psychol Psychiatry 2005;46:373-84.

31 Goswami U, Bryant P. Phonological skills and learning to read. Hillsdale, NJ: L Erlbaum, 1990.

32 Ramus F, Rosen S, Dakin SC, et al. Theories of developmental dyslexia: insights from a multiple case study of dyslexic adults. Brain 2003;126:841-65.

33 Tallal P. Auditory temporal perception, phonics, and reading disabilities in children. Brain Lang 1980;9:182-98.

34 Ahissar M, Protopapas A, Reid M, et al. Auditory processing parallels reading abilities in adults. Proc Natl Acad Sci USA 2000;97:6832-7.

35 McAnally KI, Stein JF. Auditory temporal coding in dyslexia. Proc Biol Sci 1996;263:961-5.

36 Nagarajan S, Mahncke H, Salz T, et al. Cortical auditory signal processing in poor readers. Proc Natl Acad Sci USA 1999;96:6483-8.

37 Kujala T, Myllyviita K, Tervaniemi M, et al. Basic auditory dysfunction in dyslexia as demonstrated by brain activity measurements. Psychophysiology 2000;37:262-6.

38 Schulte-Körne G, Deimel W, Bartling J, et al. Pre-attentive processing of auditory patterns in dyslexic human subjects. Neurosci Lett 1999;276:41-4.

39 Lovegrove WJ, Bowling A, Badcock D, et al. Specific reading disability: differences in contrast sensitivity as a function of spatial frequency. Science 1980;210:439-40

40 Schulte-Körne G, Bartling J, Deimel W, et al. Motion-onset VEPs in dyslexia. Evidence for visual perceptual deficit. Neuroreport 2004;15:1075-8.

41 Stein J, Walsh V. To see but not to read; the magnocellular theory of dyslexia. Trends Neurosci 1997;20:147-52

42 Talcott JB, Witton C, McLean MF, et al. Dynamic sensory sensitivity and children's word decoding skills. Proc Natl Acad Sci USA 2000:97:2952-7.

43 Nicolson RI, Fawcett AJ, Dean P. Developmental dyslexia: the cerebellar deficit hypothesis. Trends Neurosci 2001;24:508-11

44 Wolf $M$, Bowers PG. The double-deficit hypothesis for the developmental dyslexias. J Educ Psychol 1999;91:415-38.

45 Schulte-Körne G, Zucchelli M, Deimel W, et al. Interrelationship and familiality of dyslexia related quantitative measures. Ann Hum Genet 2006;70:1-16.

46 Smith SD, Kimberling WJ, Pennington BF, et al. Specific reading disability: identification of an inherited form through linkage analysis. Science 1983;219:1345-7

47 Grigorenko EL, Chang JT. An extension of affected-pedigree-member analyses to triads of relatives. Genet Epidemiol 1997;14:1005-10.

48 Schulte-Körne G, Grimm T, Nöthen MM, et al. Evidence for linkage of spelling disability to chromosome 15. Am J Hum Genet 1998;63:279-82.

49 Chapman NH, Igo RP, Thomson JB, et al. Linkage analyses of four regions previously implicated in dyslexia: confirmation of a locus on chromosome 15q. Am J Med Genet B Neuropsychiatr Genet 2004:131:67-75.

50 Cardon LR, Smith SD, Fulker DW, et al. Quantitative trait locus for reading disability on chromosome 6. Science 1994;266:276-9.

51 Fisher SE, Marlow AJ, Lamb J, et al. A quantitative-trait locus on chromosome $6 p$ influences different aspects of developmental dyslexia. Am J Hum Genet 1999;64:146-56.

52 Gayán J, Smith SD, Cherny SS, et al. Quantitative-trait locus for specific language and reading deficits on chromosome 6p. Am J Hum Genet 1999:64:157-64.

53 Fisher SE, Francks C, Marlow AJ, et al. Independent genome-wide scans identify a chromosome 18 quantitative-trait locus influencing dyslexia. Nat Genet 2002;30:86-91.

54 Kaplan DE, Gayan J, Ahn J, et al. Evidence for linkage and association with reading disability on 6p21.3-22. Am J Hum Genet 2002;70:1287-98.

55 Grigorenko EL, Wood FB, Golovyan L, et al. Continuing the search for dyslexia genes on 6p. Am J Med Genet B Neuropsychiatr Genet 2003; 1 18:89-98.

56 Fagerheim T, Raeymaekers $\mathrm{P}$, Tonnessen FE, et al. A new gene (DYX3) for dyslexia is located on chromosome 2. J Med Genet 1999;36:664-9.

57 Petryshen TL, Kaplan BJ, Hughes ML, et al. Supportive evidence for the DYX3 dyslexia susceptibility gene in Canadian families. J Med Genet 2002:39:125-6.

58 Kaminen N, Hannula-Jouppi K, Kestilä $M$, et al. A genome scan for developmental dyslexia confirms linkage to chromosome $2 \mathrm{p} 11$ and suggests a new locus on 7q32. J Med Genet 2003;40:340-5.

59 Petryshen TL, Kaplan BJ, Fu Liu M, et al. Evidence for a susceptibility locus on chromosome 6q influencing phonological coding dyslexia. Am J Med Genet 2001; 105:507-17

60 Nopola-Hemmi J, Myllyluoma B, Haltia T, et al. A dominant gene for developmental dyslexia on chromosome 3. J Med Genet 2001:38:658-64.

61 Hsiung GY, Kaplan BJ, Petryshen TL, et al. A dyslexia susceptibility locus (DYX7) linked to dopamine D4 receptor (DRD4) region on chromosome 11 p15.5. Am J Med Genet B Neuropsychiatr Genet 2004;125:112-19.

62 Rabin M, Wen XL, Hepburn M, et al. Suggestive linkage of developmental dyslexia to chromosome 1p34-p36. Lancet 1993;342:178.

63 Grigorenko EL, Wood FB, Meyer MS, et al. Linkage studies suggest a possible locus for developmental dyslexia on chromosome 1p. Am J Med Genet 2001; 105:120-9.

64 Tzenova J, Kaplan BJ, Petryshen TL, et al. Confirmation of a dyslexia susceptibility locus on chromosome 1p34-p36 in a set of 100 Canadian families. Am J Med Genet B Neuropsychiatr Genet 2004;127:117-24.

65 de Kovel CG, Hol FA, Heister JG, et al. Genomewide scan identifies susceptibility locus for dyslexia on Xq27 in an extended Dutch family. J Med Genet 2004;41:652-7.
66 Igo RP, Chapman NH, Berninger WW, et al. Genomewide scan for real-word reading subphenotypes of dyslexia: novel chromosome 13 locus and genetic complexity. Am J Med Genet B Neuropsychiatr Genet 2006;141:15-27.

67 Raskind WH, lgo RP, Chapman NH, et al. A genome scan in multigenerational families with dyslexia: identification of a novel locus on chromosome $2 q$ that contributes to phonological decoding efficiency. Mol Psychiatry 2005; 10:699-711.

68 Marino C, Giorda R, Vanzin L, et al. A locus on 15q15-15qter influences dyslexia: further support from a transmission/disequilibrium study in an Italian speaking population. J Med Genet 2004;41:42-6.

69 Morris DW, Robinson L, Turic D, et al. Family-based association mapping provides evidence for a gene for reading disability on chromosome $15 \mathrm{q}$. Hum Mol Genet 2000;9:843-8.

70 Bakker SC, van der Meulen EM, Buitelaar JK, et al. A whole-genome scan in 164 Dutch sib pairs with attention-deficit/hyperactivity disorder: suggestive evidence for linkage on chromosomes $7 p$ and 15q. Am J Hum Genet 2003;72:1251-60.

71 Cope N, Harold D, Hill G, et al. Strong evidence that KIAA0319 on chromosome $6 \mathrm{p}$ is a susceptibility gene for developmental dyslexia. Am J Hum Genet 2005;76:581-91.

72 Deffenbacher KE, Kenyon JB, Hoover DM, et al. Refinement of the 6p21. 3 quantitative trait locus influencing dyslexia: linkage and association analyses, Hum Genet 2004;115:128-38.

73 Francks C, Paracchini S, Smith SD, et al. A 77-kilobase region of chromosome 6 p22.2 is associated with dyslexia in families from the United Kingdom and from the United States. Am J Hum Genet 2004;75:1046-58

74 Meng H, Smith SD, Hager K, et al. DCDC2 is associated with reading disability and modulates neuronal development in the brain. Proc Natl Acad Sci USA 2005; 102:17053-8.

75 Schumacher J, Anthoni H, Dahdouh F, et al. Strong genetic evidence of DCDC2 as a susceptibility gene for dyslexia. Am J Hum Genet 2006;78:52-62.

76 Willcutt EG, Pennington BF, Smith SD, et al. Quantitative trait locus for reading disability on chromosome $6 \mathrm{p}$ is pleiotropic for attention-deficit/hyperactivity disorder. Am J Med Genet 2002;114:260-8.

77 Fisher SE, DeFries JC. Developmental dyslexia: genetic dissection of a complex cognitive trait. Nat Rev Neurosci 2002;3:767-80.

78 Stein CM, Schick JH, Gerry Taylor H, et al. Pleiotropic effects of a chromosome 3 locus on speech-sound disorder and reading. Am J Hum Genet 2004;74:283-97

79 Marlow AJ, Fisher SE, Francks C, et al. Use of multivariate linkage analysis fo dissection of a complex cognitive trait. Am J Hum Genet 2003;72:561-70.

80 Faraone SV, Doyle AE, Mick E, et al. Meta-analysis of the association between the 7-repeat allele of the dopamine $\mathrm{D}(4)$ receptor gene and attention deficit hyperactivity disorder. Am J Psychiatry 2001;158:1052-7.

81 Gayán J, Willcutt EG, Fisher SE, et al. Bivariate linkage scan for reading disability and attention-deficit/hyperactivity disorder localizes pleiotropic loci. J Child Psychol Psychiatry 2005;46:1045-56.

82 Loo SK, Fisher SE, Francks C, et al. Genome-wide scan of reading ability in affected sibling pairs with attention-deficit/hyperactivity disorder: unique and shared genetic effects. Mol Psychiatry 2004;9:485-93.

83 Taipale M, Kaminen N, Nopola-Hemmi J, et al. A candidate gene for developmental dyslexia encodes a nuclear tetratricopeptide repeat domain protein dynamically regulated in brain. Proc Natl Acad Sci USA 2003; 100:11553-8.

84 Wigg KG, Couto JM, Feng Y, et al. Support for EKN1 as the susceptibility locus for dyslexia on 15q21. Mol Psychiatry 2004;9:1111-21.

85 Scerri TS, Fisher SE, Francks C, et al. Putative functional alleles of DYX1C1 are not associated with dyslexia susceptibility in a large sample of sibling pairs from the UK. J Med Genet 2004;41:853-7.

86 Meng $\mathrm{H}$, Hager $\mathrm{K}$, Held $\mathrm{M}$, et al. TDT-association analysis of EKN1 and dyslexia in a Colorado twin cohort. Hum Genet 2005;1 18:87-90.

87 Marino C, Giorda R, Lorusso ML, et al. A family-based association study does not support DYX1C1 on $15 \mathrm{q} 21.3$ as a candidate gene in developmental dyslexia. Eur J Hum Genet 2005;13:491-9.

88 Bellini G, Bravaccio C, Calamoneri F, et al. No evidence for association between dyslexia and $D Y X 1 C 1$ functional variants in a group of children and adolescents from Southern Italy. J Mol Neurosci 2005;27:311-14.

89 Cope NA, Hill G, van den Bree M, et al. No support for association between dyslexia susceptibility 1 candidate 1 and developmental dyslexia. Mol Psychiatry 2005;10:237-8.

90 Harold D, Paracchini S, Scerri T, et al. Further evidence that the KIAA0319 gene confers susceptibility to developmental dyslexia. Mol Psychiatry 2006;11:1085-91.

91 Horwitz B, Rumsey JM, Donohue BC. Functional connectivity of the angular gyrus in normal reading and dyslexia. Proc Natl Acad Sci USA 1998;95:8939-44.

92 Shaywitz SE, Shaywitz BA, Pugh KR, et al. Functional disruption in the organization of the brain for reading in dyslexia. Proc Nat Acad Sci USA 1998:95:2636-41.

93 Silani G, Frith U, Demonet JF, et al. Brain abnormalities underlying altered activation in dyslexia: a voxel based morphometry study. Brain 2005; 128:2453-61.

94 Paracchini S, Thomas A, Castro S, et al. The chromosome 6p22 haplotype associated with dyslexia reduces the expression of KIAA0319, a novel gene involved in neuronal migration. Hum Mol Genet 2006;15:1659-66.

95 Nopola-Hemmi J, Taipale M, Haltia T, et al. Two translocations of chromosome $15 q$ associated with dyslexia. J Med Genet 2000;37:771-5

96 Wang $Y$, Paramasivam $M$, Thomas $A$, et al. DYX1Cl functions in neuronal migration in developing cortex. Neuroscience 2006;143:515-22. 
97 Hannula-Jouppi K, Kaminen-Ahola N, Taipale $M$, et al. The axon guidance receptor gene ROBO1 is a candidate gene for developmental dyslexia. PLoS Genet 2005; 1:e50.

98 Kidd T, Bland KS, Goodman CS. Slit is the midline repellent for the robo receptor in Drosophila. Cell 1999:96:785-94.

99 Seeger M, Tear G, Ferres-Marco D, et al. Mutations affecting growth cone guidance in Drosophila: genes necessary for guidance toward or away from the midline. Neuron 1993;10:409-26.

100 Andrews W, Liapi A, Plachez C, et al. Robol regulates the development of major axon tracts and interneuron migration in the forebrain. Development $2006 ; 133: 2243-52$.
101 Galaburda AM Kemper TL. Cytoarchitectonic abnormalities in developmental dyslexia: a case study. Ann Neurol 1979;6:94-100.

102 Galaburda AM, Sherman GF, Rosen GD, et al. Developmental dyslexia: four consecutive patients with cortical anomalies. Ann Neurol 1985:18:222-33.

103 Galaburda AM. Developmental dyslexia and animal studies: at the interface between cognition and neurology. Cognition 1994;50:133-49.

104 Kremen WS, Jacobson KC, Xian H, et al. Heritability of word recognition in middle-aged men varies as a function of parental education. Behav Genet 2005;35:417-33

105 Fisher SE, Marcus GF. The eloquent ape: genes, brains and the evolution of language. Nat Rev Genet 2006;7:9-20, . 